\title{
Physicochemical and Catalytic Characteristics of Immobilized Monometallic and Bimetallic Nickel Nanoparticles on Different Supports
}

\author{
S.F.Tantawy, S.A.Hassan", Sh.H.Gabr and M.M.Selim **\# \\ Dept. Chem., Fac. Science, Mansoura Univ., Mansoura, "Dept. \\ Chem., Fac. Science, Ain Shams Univ. and ${ }^{* *}$ National Research \\ Center, Cairo, Egypt.
}

\begin{abstract}
T $\mathrm{N}$ THIS work pure Ni from different precursors and mixed $\mathrm{Ni} / \mathrm{Cu}$, $1 \mathrm{Ni} / \mathrm{Co}$ nano metals were prepared from their chlorides supported on silica from rice straw (RSS) or cation exchange resin $\left(\mathrm{RNa}^{+}\right)$. The prepared catalysts were characterized by using XRD and TEM. The catalytic activity was tested in $\mathrm{H}_{2} \mathrm{O}_{2}$ decomposition. The results revealed that the obtained metals were in nano size. The results of decomposition of hydrogen peroxide showed that the activity of nano nickel catalyst prepared from chloride was more than that from sulfate and nitrate. The most active catalyst among all the prepared samples was Co-Ni/RSS.
\end{abstract}

In the past two decades, considerable attention has been devoted to the synthesis of metallic nano particles specially nano-nickel particles because of their unusual properties that differ from either the bulk or single atoms. These materials offered excellent models for studying the relationship between the size, shape and structure of the individual particles and their unique properties. Many of these properties have found applications in several fields, e.g., electronics ${ }^{(1-3)}$, catalysis ${ }^{(2,4,5)}$, pigments ${ }^{(2)}$ and metallurgy ${ }^{(2)}$.

For synthesis of various kinds of metal nanoparticles, some metals such as nickel, copper and iron were relatively difficult because they were easily oxidized. Several synthetic methods have been developed, such as vapor phase method ${ }^{(6,7)}$, spray pyrolysis ${ }^{(8)}$, micro-emulsion ${ }^{(9)}$, polyl process ${ }^{(8,9)}$ and electrochemical reduction for the preparation of Ni nanopowders. Among these methods, the chemical reduction method in aqueous solution has been investigated intensively due to its better capabilities for controlling composition, size and shape of Ni powders.

Synthesis of Ni nanoparticles by hydrazine reduction of nickel chloride in ethylene glycol at $60^{\circ} \mathrm{C}$ without soluble polymer as protective agent was studied in many recent works ${ }^{(e . g ., 10)}$, as $\mathrm{pH}$ and temperature dependent reducing ability of hydrazine makes the reduction rate easily controllable. It was reported that an appropriate amount of $\mathrm{NaOH}$ was necessary for the formation of pure Ni nanoparticles ${ }^{(10)}$.

\# Corresponding author : E-mail-mmaselim@yahoo.com 
The supported nanonickel catalysts have been widely studied and used due to their very high activity in hydrogenation, hydro treating and stream-reforming reactions ${ }^{(11)}$. Supported Ni hydrogenation catalysts on silica, alumina and zeolite have been studied and compared in a previously published work ${ }^{(12)}$. Supported nickel nano catalysts could also be synthesized on resin surface and could be striped on the resin surface ${ }^{(13)}$.

On the other hand, bimetallic catalysts have become the subject of intensive efforts both in academia and industry, the special properties of which are derived from an electronic ligand effect. These bimetallic powders have provided the first example of $\mathrm{Cu}$-based catalysts with high activity, selectivity and stability against air for the selective hydration of acrylonitrile to acrylamide ${ }^{(13)}$. There are only a few reports on the synthesis of monometallic nanoparticles (mono-MNPs) and bimetallic nanoparticles (bi-MNPs) on resin surface and in some cases isolation of the nanoparticles on the cationic as well as the anionic exchange resin surface. $\mathrm{Ni}, \mathrm{Au}$ and various bimetallic nanoparticles have successfully been obtained on a resin surface, where a layer-by-layer deposition technique in some cases helped the formation of core shell bimetallic structures ${ }^{(12)}$. In general, supported bimetallic catalysts are very interesting materials because one metal can tune and/or modify the catalytic properties of the other metal as a result of both electronic and structural effects ${ }^{(14)}$. Bimetallic catalysts supported on high surface area carriers, such as, silica and alumina, have attracted considerable attention recently because of their better performance in catalytic reactions which differs significantly from that of the corresponding monometallic counterparts ${ }^{(14)}$. They are superior compared with those made of pure metals, in terms of activity, selectivity, stability, and resistance to poisoning ${ }^{(15)}$. For example, bimetallic nanoparticles (bi-MNPs) are preferred heterogeneous catalysts in petroleum reforming processes ${ }^{(15)}$. This is the case for $\mathrm{Ni}$-based bimetallic particles containing copper, which exhibit better catalytic activity ${ }^{(16)}$ and selectivity ${ }^{(16)}$ than monometallic nickel. To improve the properties of pure $\mathrm{Ni}$ and $\mathrm{Cu}$ powders, several methods have been proposed for the preparation of bimetallic and alloyed $\mathrm{Ni}-\mathrm{Cu}$ particles. Reduction of a mixture of nickel and copper compounds under hydrogen has been used to prepare $\mathrm{Ni}-\mathrm{Cu}-\mathrm{Al}{ }^{(16)}$ and $\mathrm{Ni}-\mathrm{Cu} / \mathrm{Al}_{2} \mathrm{O}_{3}{ }^{(16)}$ catalysts, and $\mathrm{Ni}-\mathrm{Cu}$ alloys ${ }^{(16)}$.

The present work was undertaken to synthesize the monometallic $\mathrm{Ni}$ nanoparticles from different precursors using hydrazine hydrate as $\mathrm{H}_{2}$ source for reduction. For immobilizing $\mathrm{Ni}$ nano particles, in varying loadings, two chemically different supports were used, namely, rice straw silica (RSS), extracted from acid-leached rice straw and converted to silica xerogel, as an inorganic support and commercial cation exchange resin, $\left(\mathrm{RNa}^{+}\right)$of Dowex type, as an organic support. For synthesis of immobilized bimetallic Ni nano catalysts, monometallic Ni nanoparticles (mono-NiNP) were studied in combination with $\mathrm{Co}$ and $\mathrm{Cu}$ nanoparticles, added in different sequences on $\mathrm{RSS}$ and $\mathrm{RNa}^{+}$ supports. Comparison was made of the various physicochemical characteristics and catalytic activity ( $\mathrm{inH}_{2} \mathrm{O}_{2}$-decomposition, in an alkaline medium.

Egypt. J. Chem. 57, No.3 (2014) 


\section{Experimental}

Synthesis of monometallic Ni nano particles (Ni-NPs)

$5 \mathrm{~g}$ of nickel salt $\left(\mathrm{Cl}^{-}, \mathrm{SO}_{4}{ }^{2-}\right.$ or $\left.\mathrm{NO}_{3}^{-}\right)$were dissolved in $100 \mathrm{ml}$ ethylene glycol with stirring at $80^{\circ} \mathrm{C}$. An appropriate amount of hydrazine monohydrate was added to the solution with continuous stirring. A blue violet or pink precipitate was formed depending on the molar ratio of $\left[\left(\mathrm{N}_{2} \mathrm{H}_{4}\right) / \mathrm{Ni}^{2+}\right]$. To the nickel hydrazine complex solution few drops of concentrated solution of $\mathrm{NaOH}$ were added with continuous stirring and the reduction was completed, i.e. the solution become colorless. The product in each case was filtered and washed with ethyl alcohol several times before using.

Synthesis of immobilized monometallic Ni particles supported on rice straw silica (RSS)

Extraction of pure silica from rice straw

The rice straw washed with water for removal of fine dust on the surface. The washed rice straw digested by refluxing in $3 \mathrm{~N}$ of $\mathrm{HNO}_{3}$ for $48 \mathrm{hr}$ until converted into white rice straw as white precipitate. After filtration, washing for several times by distilled water, the product was dried then calcined at $600^{\circ} \mathrm{C}$ for $4 \mathrm{hr}$.

For each $1 \mathrm{~g}$ of produced white rice straw powder, $50 \mathrm{ml}$ of $1 \mathrm{~N} \mathrm{NaOH}$ were added, while stirring overnight and the unlike material was removed by filtration. The filtrate solution (sodium silicate solution) neutralized with $1 \mathrm{~N}$ nitric acid $\mathrm{HNO}_{3}$ drop wise under stirring at room temperature, until formation of silica xerogel. The silica gel formation was started at $\mathrm{pH}=8.3$ and the final $\mathrm{pH}$ was 6.5. The formed silica gel was washed with water to remove the nitrate and dried at $100^{\circ} \mathrm{C}$. The dried silica gel was heated for $4 \mathrm{hr}$ at $550^{\circ} \mathrm{C}$ to obtain pure silica (RSS) grained to $0.5 \mathrm{~mm}$ and stored in vacuum. $\mathrm{RNa}^{+}$

Preparation of immobilized monometallic nano-nickel supported on RSS or

Calculated amount of the prepared rice straw silica (RSS) considered as inorganic support was impregnated with aqueous solution of nickel chloride hexahydrate with different loadings from 1.0 to $8.0 \mathrm{wt} \% \mathrm{Ni}$.

The prepared supported nickel chloride/RSS introduced into a flask with $100 \mathrm{ml}$ of ethylene glycol as solvent and stirred at $80-90^{\circ} \mathrm{C}$. By adding $10 \mathrm{ml}$ of hydrazine hydrate (98\%), a complex of nickel hydrazine was formed. After that, drops of saturated solution of sodium hydroxide were added; the suspension was turned to black color with colorless solution.

The same procedure was applied for the immobilized samples on the cation exchange resin $\left(\mathrm{RNa}^{+}\right)$(organic support)

Preparation of immobilized Ni-based bimetallic nano metals supported on $\mathrm{RSS}$ or $\mathrm{RNa}^{+}$

A series of silica or resin immobilized Ni-based bimetallic catalysts $\mathrm{M}$ $\mathrm{M}_{1} / \mathrm{RSS}$ or $\mathrm{RNa}^{+}\left(\mathrm{M}=\mathrm{Ni}\right.$ and $\mathrm{M}_{1}=\mathrm{Cu}$ or $\left.\mathrm{Co}\right)$ were prepared by impregnation 
method. Both metals $\left(\mathrm{M} \& \mathrm{M}_{1}\right)$ were loaded in 1:1 weight ratio (based on metals) keeping the \% loading constant at $1 \mathrm{wt} \%$ bimetals and 99 wt \% of silica (RSS) or resin $\left(\mathrm{RNa}^{+}\right)$.

In a typical preparation

(i) The required quantities of the respective chloride precursor salts were dissolved in distilled water and mixed together. To this mixture solution, the required quantity of rice straw silica (RSS) was added and the resulting slurry was stirred to obtain homogeneity followed by drying.

(ii) To the solution of nickel chloride, the required quantity of $\mathrm{RSS}$ or $\mathrm{RNa}^{+}$was added and the resulting slurry was stirred to obtain homogeneity, followed by drying. Then the other metal $(\mathrm{Cu}$ or $\mathrm{Co})$ chloride solution was added. The resulting slurry was stirred to obtain homogeneous solution of the two metal salts on rice straw silica, followed by drying.

(iii) The same manner of the above addition was preceded, by changing the addition order of the metal salts solutions.

Each of impregnated samples was introduced in the reaction flask with $100 \mathrm{ml}$ of ethylene glycol as solvent and stirred at $80-90^{\circ} \mathrm{C} .10 \mathrm{ml}$ of hydrazine mono hydrate $98 \%$ were added, a complex of bimetal hydrazine was formed. After that drops of saturated solution of sodium hydroxide was added. The suspension was turned to black color after few minutes, with the formation of colorless solution.

Characterization of the catalysts

$X$-Ray Diffraction (XRD) analysis

$X$-Ray powder diffraction (XRD) patterns of various samples were recorded on a Siemens D-5000 diffractometer, using Ni-filtered $\mathrm{Cu} \mathrm{K}_{\alpha}(0.15418 \mathrm{~nm})$ radiation source.

Transmission Electron Microscopy Analysis (TEM)

Transmission Electron Microscopy (TEM) images were taken using TEM model EM10 Zeiss instrument with 40000 magnification and $60 \mathrm{KV}$ power.

\section{Results and Discussion}

\section{$X R D$ results and discussion}

The following figures show the results of X-ray diffraction analysis of $\mathrm{Ni}$ monometallic samples prepared from nickel salts.

Figures 1-3 show the XRD diffractograms of nickel metal prepared from different precursors. The patterns are only related to the crystalline $\mathrm{Ni}^{\circ}$ metal. The X-ray data allow investigating the effect of nickel precursors on the crystallinity and crystallite size of nickel metal phases present in various solids. The heights of main diffraction peaks of $\mathrm{Ni}$ were taken for measuring their crystallite size, according to the different precursor salts, the order of crystallinity of $\mathrm{Ni}$ according to the type of precursor is $\left(\mathrm{NO}_{3}{ }^{-}>\mathrm{SO}_{4}{ }^{2-}>\mathrm{Cl}^{-}\right)$.

Egypt. J. Chem. 57, No.3 (2014) 


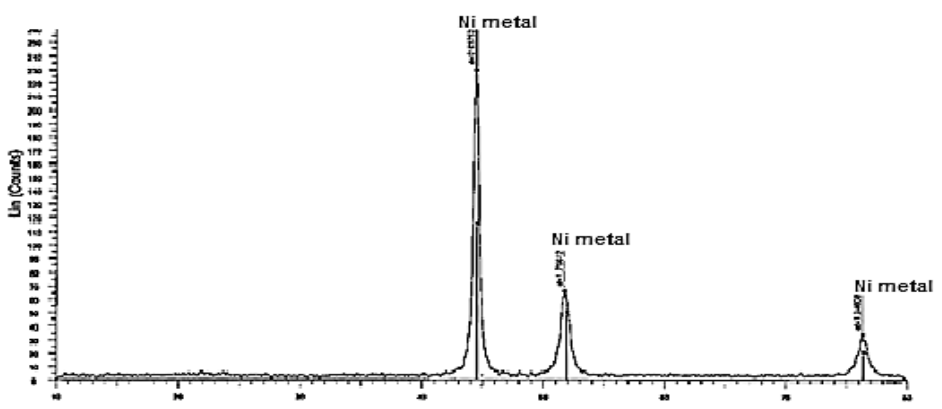

Fig. 1. XRD of $\mathrm{Ni}^{\circ}$ prepared from $\mathrm{Ni}\left(\mathrm{NO}_{3}\right)_{2} \cdot 6 \mathrm{H}_{2} \mathrm{O}$.

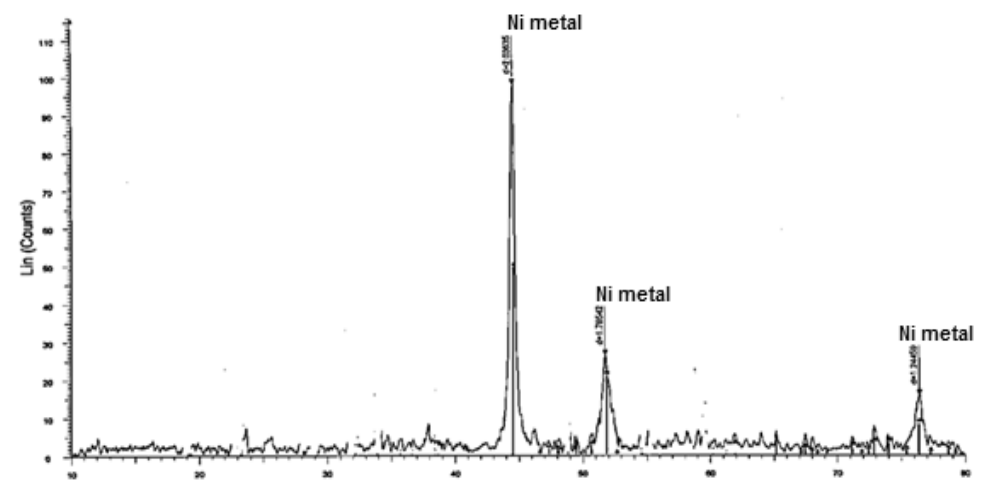

Fig. 2. XRD of $\mathrm{Ni}^{\circ}$ prepared from $\mathrm{NiSO}_{4} \cdot 6 \mathrm{H}_{2} \mathrm{O}$.

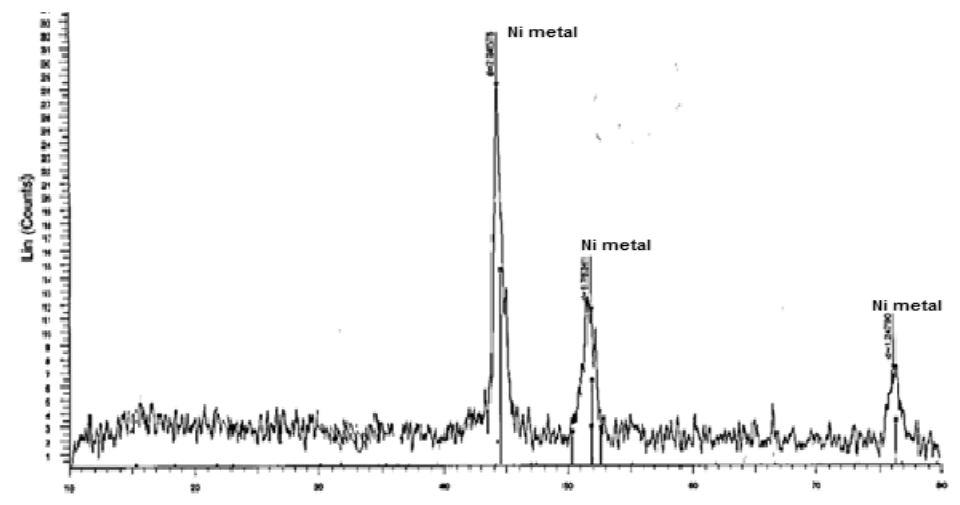

Fig. 3. XRD of $\mathrm{Ni}^{\circ}$ prepared from $\mathrm{NiCl}_{2} \cdot 6 \mathrm{H}_{2} \mathrm{O}$.

Egypt. J. Chem. 57, No.3 (2014) 
The difference of crystallite size of nickel can be attributed to the complex formed from nickel chloride salts and hydrazine which was rapidly decomposed than complex formed from hydrazine and other salts, leading to small crystallite size. In this method, hydrazine mono hydrate has been used as reducing agent for the preparation of nickel metal particles, because $\mathrm{pH}$ and temperature dependent reducing ability of hydrazine makes the reduction rate easily controllable. So the addition of $\mathrm{NaOH}$ completed the reduction process of the nickel hydrazine complex solution, the color of the solution gradually changes due to the formation of nickel.

It is known that the reaction between hydrazine and Ni salts is as follows; ${ }^{(17-18)}$.

$$
\begin{aligned}
& \mathrm{NiCl}_{2}+\mathrm{nN}_{2} \mathrm{H}_{4} \rightarrow\left[\mathrm{Ni}\left(\mathrm{N}_{2} \mathrm{H}_{4}\right)_{\mathrm{n}}\right] \mathrm{Cl}_{2}, \mathrm{n}=2,3 \\
& \mathrm{NiSO}_{4}+\mathrm{nN}_{2} \mathrm{H}_{4} \rightarrow\left[\mathrm{Ni}\left(\mathrm{N}_{2} \mathrm{H}_{4}\right)_{\mathrm{n}}\right] \mathrm{SO}_{4}, \quad \mathrm{n}=2,3 \\
& \mathrm{Ni}\left(\mathrm{NO}_{3}\right)_{2}+\mathrm{nN}_{2} \mathrm{H}_{4} \rightarrow\left[\mathrm{Ni}\left(\mathrm{N}_{2} \mathrm{H}_{4}\right)_{\mathrm{n}}\right]\left(\mathrm{NO}_{3}\right)_{2}, \quad \mathrm{n}=2,3 \\
& {\left[\mathrm{Ni}\left(\mathrm{N}_{2} \mathrm{H}_{4}\right)_{\mathrm{n}}\right] \mathrm{X}+2 \mathrm{NaOH} \rightarrow \mathrm{Ni}(\mathrm{OH})_{2}+\mathrm{nN}_{2} \mathrm{H}_{4}+2 \mathrm{NaX}} \\
& 2 \mathrm{Ni}(\mathrm{OH})_{2}+\mathrm{N}_{2} \mathrm{H}_{4} \rightarrow 2 \mathrm{Ni}+\mathrm{N}_{2}+4 \mathrm{H} 2 \mathrm{O} \\
& \left(\mathrm{X}=\left(\mathrm{NO}_{3}{ }^{-}, \mathrm{SO}_{4}{ }^{2-}, \mathrm{Cl}^{-}\right)\right.
\end{aligned}
$$

$X R D$ results and discussion of RSS as supporting material of immobilized $\mathrm{Ni}$ based mono- and bimetallic nanocatalysts on RSS.

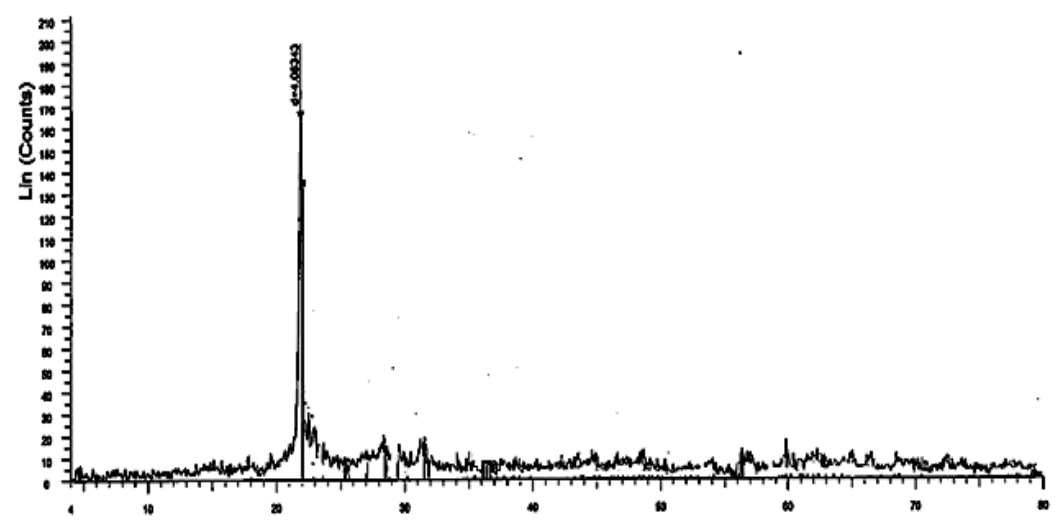

Fig. 4. XRD of silica (RSS) extracted from rice straw $\left(\mathrm{SiO}_{2}\right.$ Cristobalite).

PS. All samples with less than 5\% metal showed no patterns for the supported metals.

Figure 5 shows the XRD of 8 wt. \% Ni /RSS. From this figure it can be seen that two types of patterns were observed, the first for crystalline cristobalite and the others for sodium chloride. No patterns for $\mathrm{Ni}^{\circ}$ crystalline phase were observed. This means that the reduction process produced non crystalline nano $\mathrm{Ni}$ on silica surface. 


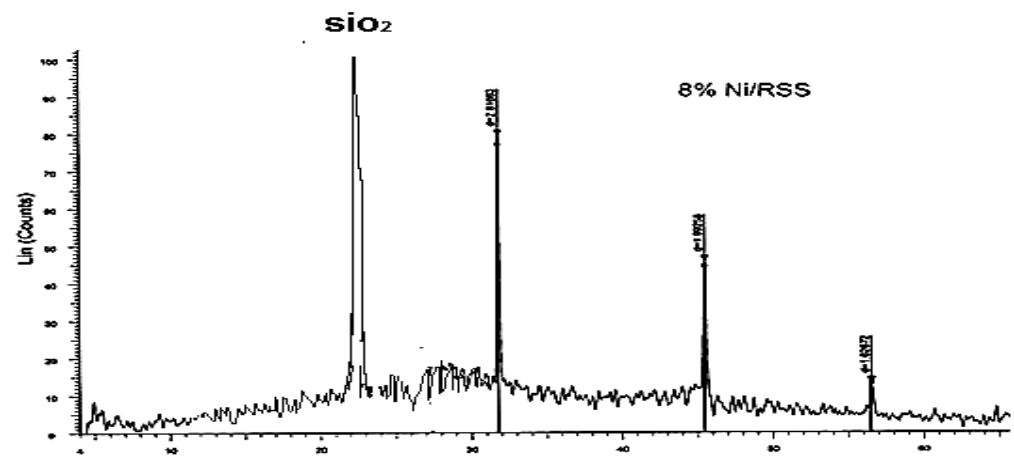

Fig. 5. XRD of 8 wt \% Ni/RSS.

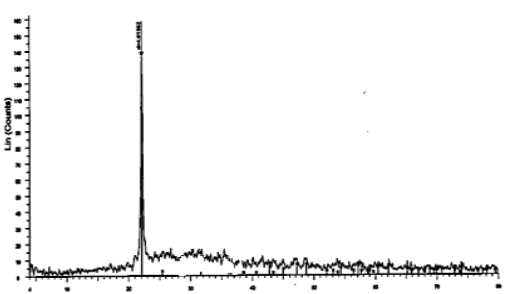

a- $0.5 \% \mathrm{Cu}-0.5 \% \mathrm{Ni} / \mathrm{RSS}$

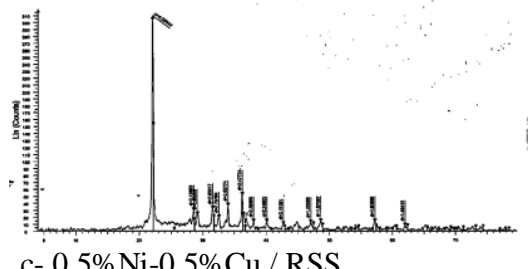

c- $0.5 \% \mathrm{Ni}-0.5 \% \mathrm{Cu} / \mathrm{RSS}$

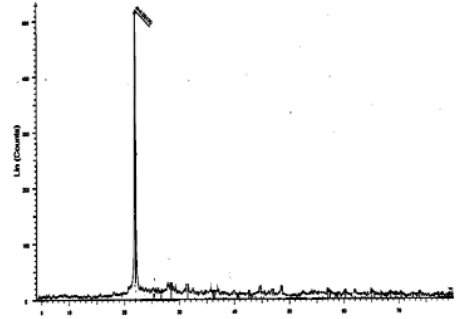

b- $0.5 \% \mathrm{Ni}-0.5 \% \mathrm{Cu} / \mathrm{RSS}$

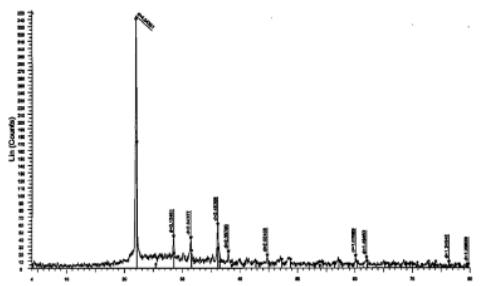

d- $0.5 \%$ Co- $0.5 \% \mathrm{Ni} / \mathrm{RSS}$

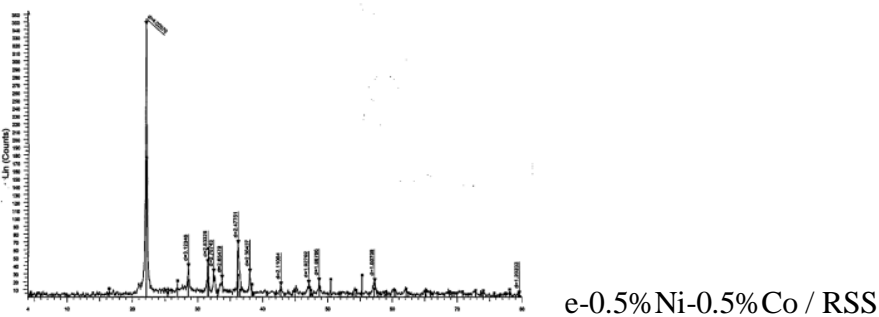

Fig. 6. XRD- of mixed oxides on RSS

Egypt. J. Chem. 57, No.3 (2014) 
$X R D$ results and discussion of $\mathrm{RNa}^{+}$as supporting material of immobilized $\mathrm{Ni}$-based monometallic and bimetallic Nanocatalysts on $\mathrm{RNa}^{+}$.

Figure 7 illustrates the XRD of non-crystalline cation exchange resin with sodium $\left(\mathrm{RNa}^{+}\right)$.

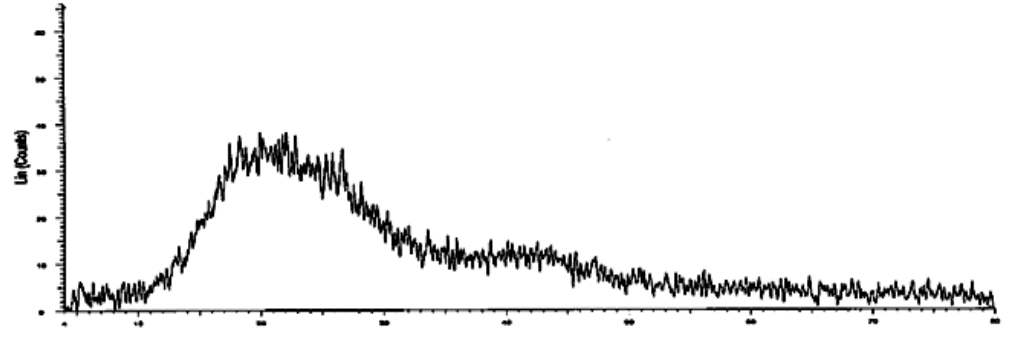

Fig. 7. XRD of cation exchange resin with sodium (RNa+) .

Figure 8 shows the XRD of 8 wt $\% \mathrm{Ni} / \mathrm{RNa}^{+}$. The detectable patterns are due to the $\mathrm{NaCl}$ produced as a result of the ion exchange of the $\mathrm{Na}^{+}$in the resin and $\mathrm{Cl}^{-}$from $\mathrm{NiCl}_{2}$. Ni introduced in resin as ions and reduced in situ by hydrazine to form non crystalline $\mathrm{Ni}^{\circ}$ metal.

$$
\begin{aligned}
& \mathrm{NiCl}_{2}+2 \mathrm{NaOH} \rightarrow \mathrm{Ni}(\mathrm{OH})_{2}+2 \mathrm{NaCl} \\
& 2 \mathrm{Ni}(\mathrm{OH})_{2}+\mathrm{N}_{2} \mathrm{H}_{4} \rightarrow 2 \mathrm{Ni}+\mathrm{N}_{2}+4 \mathrm{H}_{2} \mathrm{O}
\end{aligned}
$$

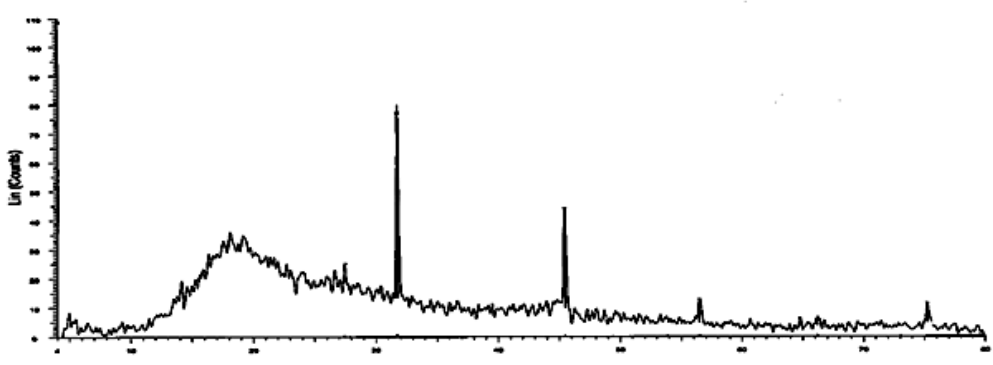

Fig. 8. XRD of 8 wt \% $\mathrm{Ni} / \mathrm{RNa}^{+}$.

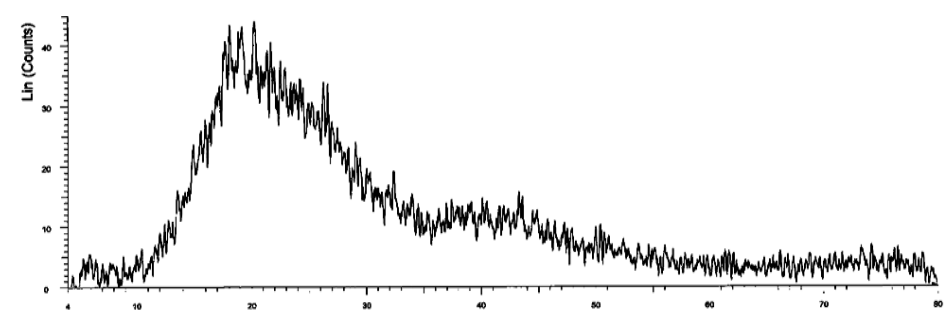

Fig. 9. Shows the XRD of 1 wt. $\% .0 .5 \% \mathrm{Cu}-0.5 \% \mathrm{Ni} / \mathrm{RNa}+$ l.

Egypt. J. Chem. 57, No.3 (2014) 


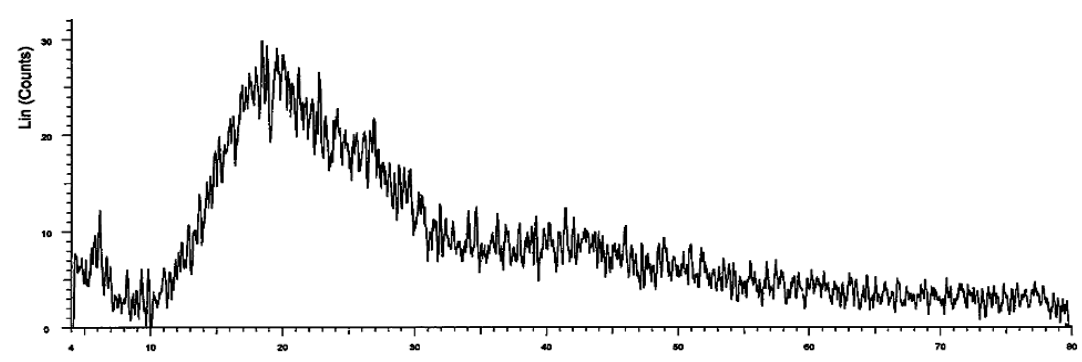

Fig. 10. Shows XRD of $1 w t \% .0 .5 \% \mathrm{Ni}-0.5 \% \mathrm{Cu} / \mathrm{RNa}^{+}$.

\section{Transmission Electron Microscopic (TEM) characterization}

Figure 11 represent TEM images of $\mathrm{Co}$ and $\mathrm{Ni}$ nano particles which were supported on silica by sequent addition, respectively $(0.5 \% \mathrm{Ni}-0.5 \% \mathrm{Co}) / \mathrm{RSS}$, had spherical shapes with weak agglomerate; their size was ranging from 12 to 23 $\mathrm{nm}$, which agrees with the value calculated from XRD patterns by Scherer equation.

Figure 12 represents TEM images of $\mathrm{Ni}$ and Co nano particles, which had spherical shapes with weak agglomerate; its size were 12 - $13 \mathrm{~nm}$.

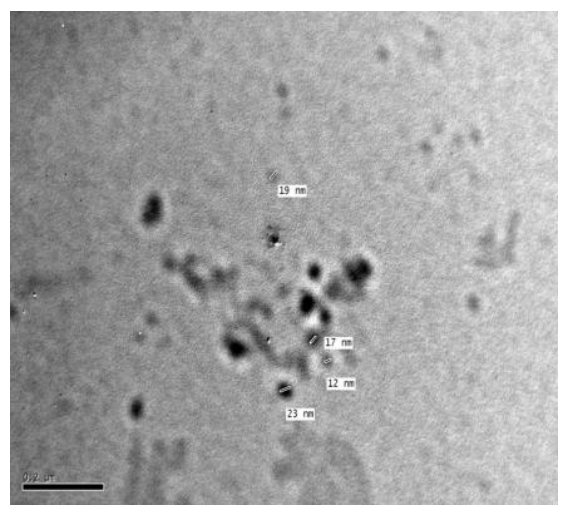

Fig.11. TEM of $0.5 \% \mathrm{Ni}-0.5 \% \mathrm{Co} / \mathrm{RSS}$.

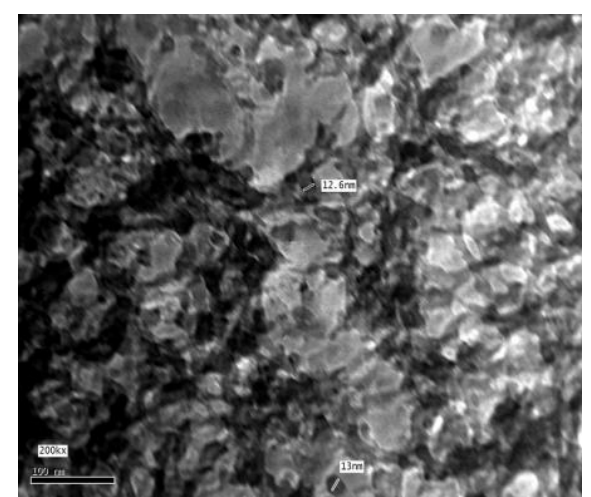

Fig.12. TEM (Co-Ni) /RSS.

Figure 13 represents the TEM image of Ni/RSS nanocatalyst, the uniform Ni nanoparticles over surface of silica were observed with weak agglomerate and the average size was ranging from 12 to $17 \mathrm{~nm}$ on which agree with the value calculated from XRD patterns. Figure 14 represents TEM image of $8 \%$ wt.Ni /RSS nanocatalyst, the uniform Ni nanoparticles over surface of silica were observed with weak agglomerate and the average size was very nano, ranging from 1 to $2 \mathrm{~nm}$ on which agrees with the value calculated from XRD patterns. 


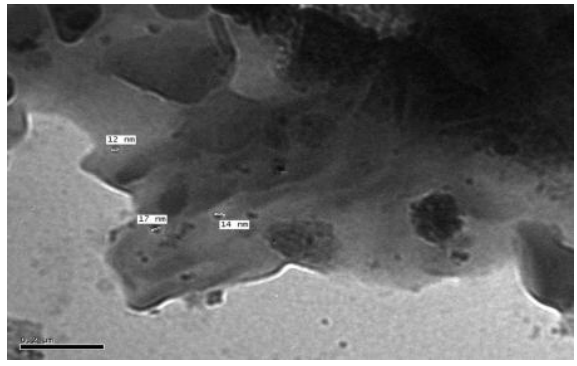

Fig. 13. TEM of 0.5 wt. \% Ni / RSS .

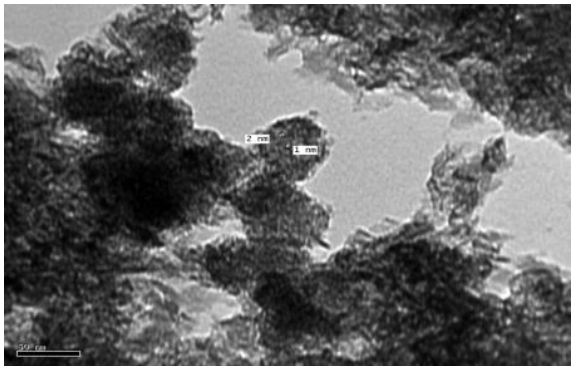

Fig. 14. TEM of $8 \%$ Ni / RSS.

Figure 15 represents TEM image of (Ni-Co)/RSS nanocatalyst, the uniform $\mathrm{Ni}$ and Co nanoparticles on silica surface were observed with weak agglomerate and the average size was $13 \mathrm{~nm}$ on which agree with the value calculated from XRD patterns by Scherer equation.
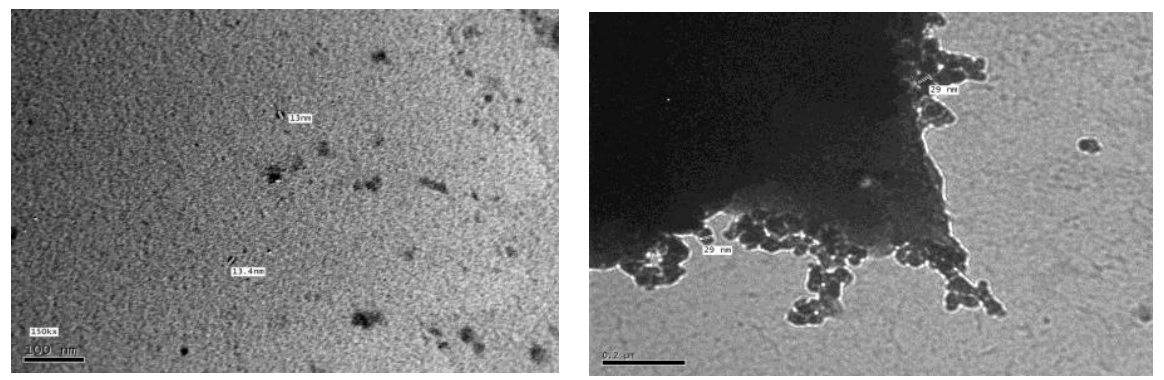

Fig. 15. TEM of $(0.5 \% \mathrm{Ni}-0.5 \% \mathrm{Co}) / \mathrm{RSS}$.

Fig. 16. TEM of $0.5 \mathrm{wt} . \% \mathrm{Ni} / \mathrm{RNa}^{+}$.

Figure 17 represents the TEM image of $8 \% \mathrm{wt} . \mathrm{Ni} / \mathrm{RNa}^{+}$nanocatalyst, the uniform $\mathrm{Ni}$ nanoparticles over surface of silica were observed with weak agglomerate and the average size was ranging from 8 to $29 \mathrm{~nm}$ on which agrees with the value calculated from XRD patterns.

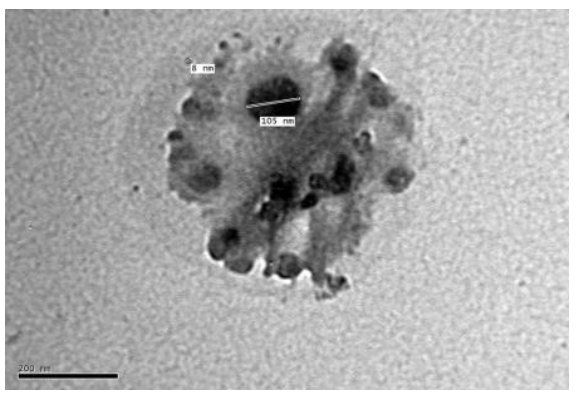

Fig. 17. TEM of $8 \mathrm{wt} . \% \mathrm{Ni} / \mathrm{RNa}^{+}$.

Egypt. J. Chem. 57, No.3 (2014) 
Catalytic activity results

The prepared nano catalysts were used for the decomposition of hydrogen peroxide as a catalytic model reaction to measure their activities. It is known that at room temperature, hydrogen peroxide decomposes very slowly. The presence of the catalyst accelerates the decomposition process.

$$
2 \mathrm{H}_{2} \mathrm{O}_{2} \rightarrow \mathrm{O}_{2}+2 \mathrm{H}_{2} \mathrm{O}
$$

The catalytic activity of various catalyst samples was tested in a simple model reaction, namely, liquid-phase decomposition of $\mathrm{H}_{2} \mathrm{O}_{2}$ in an alkaline medium $(\mathrm{pH}=11)$, using $1 \mathrm{~N} \mathrm{KOH}$, where it presents as perhydroxyl ions ${ }^{(19)}$. The rate of the reaction could be followed by recording the volume of evolved oxygen. The kinetics was followed gasometrically through $\mathrm{HO}_{2}^{-}$measuring the volume of oxygen evolved according to

$$
2 \mathrm{HO}_{2}^{-}=\mathrm{O}_{2}+2 \mathrm{OH}^{-}
$$

From the volume and time, the catalytic activity of each catalyst sample was determined. The catalysts used were $\mathrm{Ni}, \mathrm{Cu}$ and $\mathrm{Co}$ in the nano size, nonsupported and supported with different loadings (1.0, 2.0, 4.0 and 8.0 wt. \%) and bi-metallic nanoparticles supported on RSS or RNa+.

Catalytic activity results of $\mathrm{Ni}$

Catalytic of pure Ni: To install the $\mathrm{pH}$ of the model reaction test, a preliminary experiment was accomplished by using pure $\mathrm{Ni}$ from its chloride in hydrogen peroxide decomposition at different values of $\mathrm{pH}(10,10.5,11,11.5$ and 12 ) at $30^{\circ} \mathrm{C}$ (Fig.18).

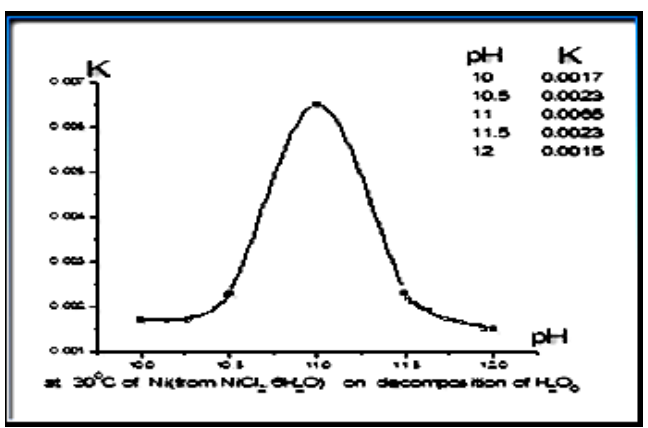

Fig.18. Effect of $\mathrm{pH}$ on the rate of hydrogen peroxide decomposition.

From Fig.18, the $\mathrm{pH} 11$ was the favorable one with maximum rate, so that the catalytic decomposition reaction of hydrogen peroxide was performed at $\mathrm{pH} 11$ for all samples.

From the following figures, pure Ni nanoparticles from its chloride was the best catalyst in comparison with others one from sulfate or nitrate in this reaction. 


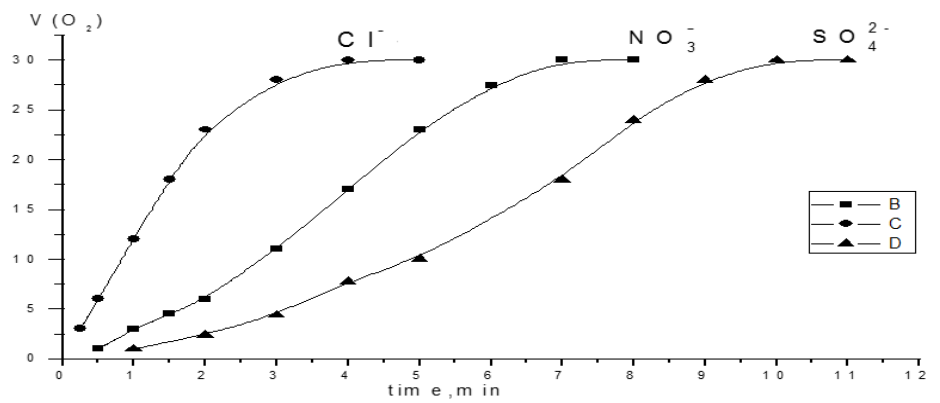

Fig. 19. Decomposition of $\mathrm{H}_{2} \mathrm{O}_{2}$ at $30^{\circ} \mathrm{C}$ over Ni nanocatalyst prepared from different precursors.

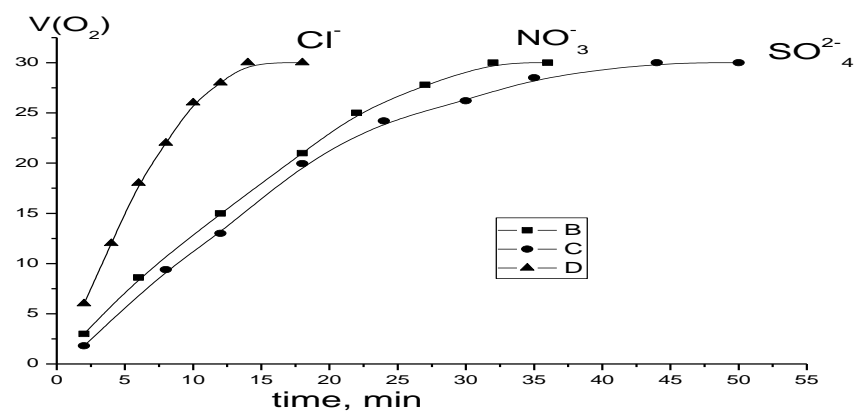

Fig. 20. Decomposition of $\mathrm{H}_{2} \mathrm{O}_{2}$ at $35^{\circ} \mathrm{C}$ over Ni nanocatalyst prepared from different precursors.

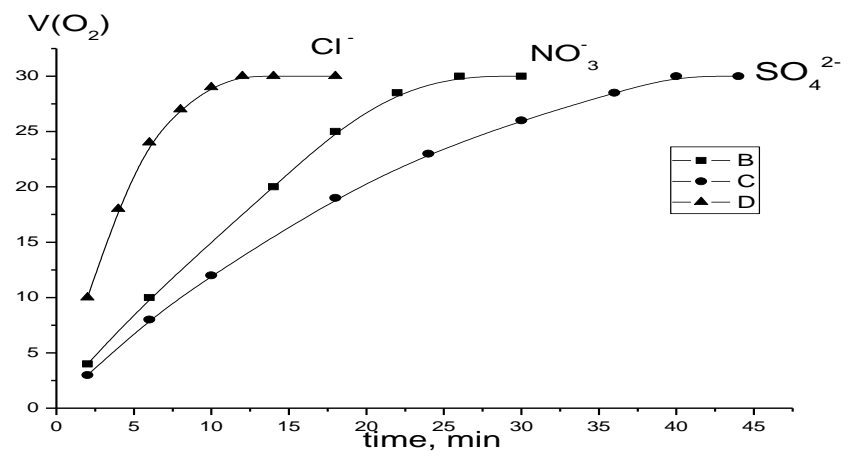

Fig. 21. Decomposition of $\mathrm{H}_{2} \mathrm{O}_{2}$ at $40^{\circ} \mathrm{C}$ over Ni nanocatalyst prepared from different precursors.

From the above Figures (19-21), it can be seen that the increase of reaction temperature, is accompanied by the increase of the activity of the catalysts. Therefore, nickel from its chloride was chosen to compare with $\mathrm{Co}$ and $\mathrm{Cu}$ chloride, also was chosen for loading on RSS or $\mathrm{RNa}^{+}$to study its activity.

Egypt. J. Chem. 57, No.3 (2014) 
From secondary preliminary test, for comparison, catalysts with pure $\mathrm{Ni}, \mathrm{Cu}$ and Co-metals from their chlorides were performed in hydrogen peroxide decomposition. The results revealed that the order of the activity was $\mathrm{Ni}<\mathrm{Cu}<$ Co as seen from Fig. 22.

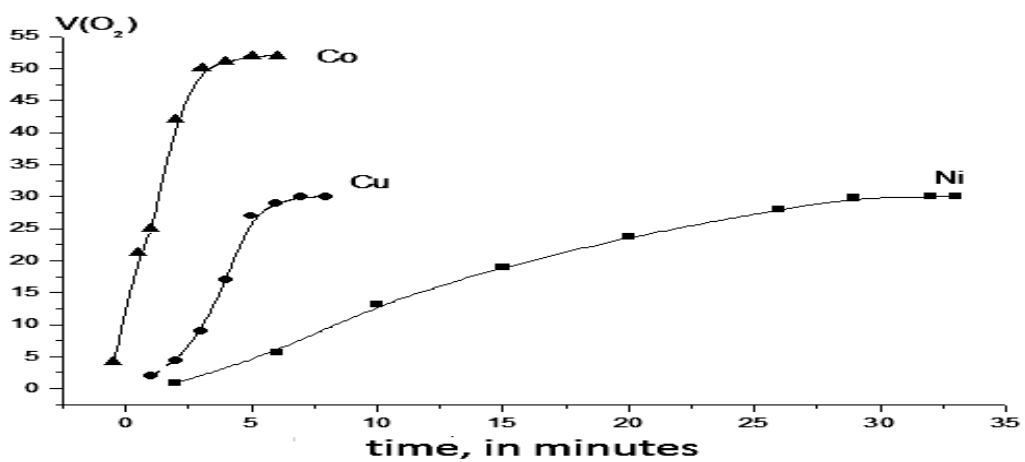

Fig. 22. Decomposition of $\mathrm{H}_{2} \mathrm{O}_{2}$ at $35^{\circ} \mathrm{C}$ over $\mathrm{Ni}, \mathrm{Cu}$ and $\mathrm{Co}$ nano catalysts prepared from their chlorides.

From Fig. 22; it can be seen that, nano cobalt is the most active catalyst in this reaction.

Catalytic activity results of Ni/RSS or Ni/RNa ${ }^{+}$: From Fig. (23 and 24), it is obvious that, $\mathrm{Ni} / \mathrm{RNa}^{+}$nano catalysts with different loads were more active than $\mathrm{Ni} /$ RSS nanocatalyst with the same different loads in decomposition of hydrogen peroxide at constant conditions. Therefore, the type of the support exists certain role on the activity of the nanocatalyst, i.e., organic support or inorganic support.

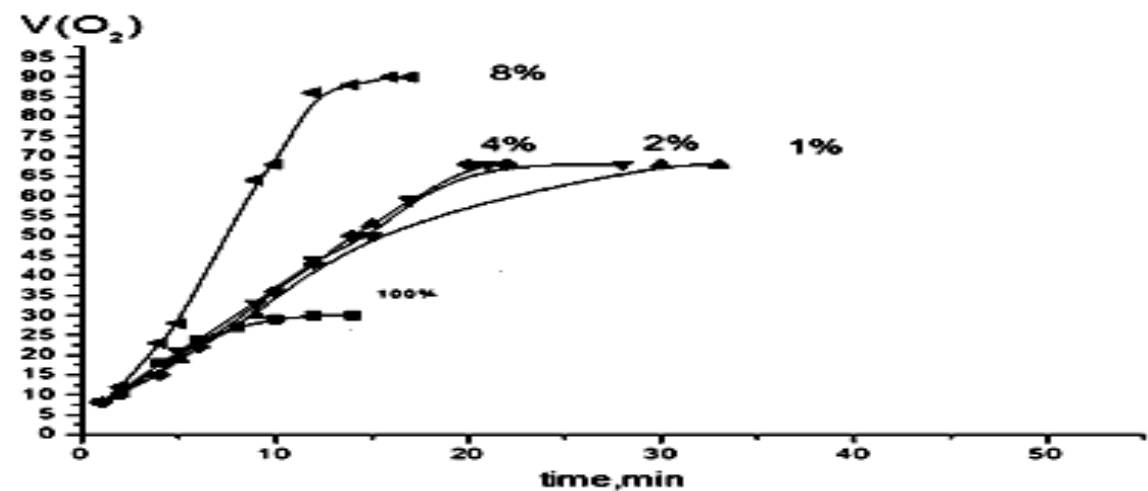

Fig. 23. Decomposition of $\mathrm{H}_{2} \mathrm{O}_{2}$ at $40^{\circ} \mathrm{C}$ over $\mathrm{Ni} / \mathrm{RNa}^{+}$nanocatalyst prepared with different loading, and $100 \%$ pure $\mathrm{Ni}$ without support. ( $\mathrm{Ni}$ precursor was $\mathrm{NiCl}_{2}$ ). 


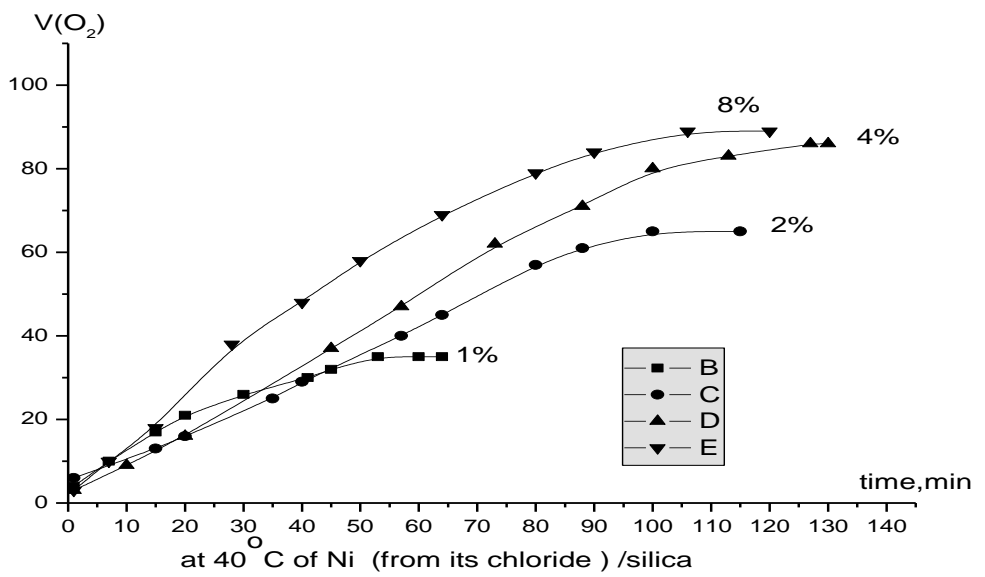

Fig. 24. Decomposition of $\mathrm{H}_{2} \mathrm{O}_{2}$ at $40^{\circ} \mathrm{C}$ over $\mathrm{Ni} / \mathrm{RSS}$ nanocatalyst prepared with different loading (from 1 to $8 \mathrm{wt} \%$ ), $\mathrm{Ni}$ precursor was $\mathrm{NiCl}_{2}$.

Catalytic activity results of bimetallic, $\mathrm{Ni}$ and $\mathrm{Cu}$ or Co)/RSS or $\mathrm{RNa}^{+}$: Modification of nickel with copper or cobalt improved the activity of nickel, and the order of the activity was: $1.0 \% \mathrm{Ni} / \mathrm{RSS}<(0.5 \% \mathrm{Ni}-0.5 \% \mathrm{Cu}) / \mathrm{RSS}<(0.5 \% \mathrm{Ni}-$ $0.5 \% \mathrm{Co}) / \mathrm{RSS}$. This arrangement assures that the cobalt actually exhibits the highest activity.

From Fig. (25 and 26), it can be observed that the combination of Ni with $\mathrm{Co}$ and $\mathrm{Cu}$ led to the enhancement of the activity of pure nickel catalyst i.e., the catalyst. (Ni-Co) more active than $(\mathrm{Ni}-\mathrm{Cu})$ and pure $\mathrm{Ni}$.

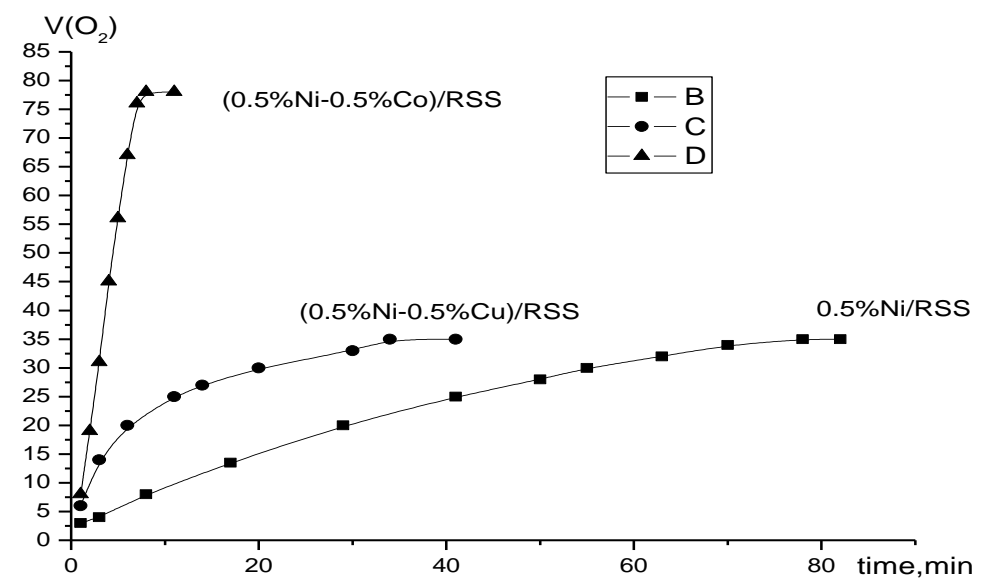

Fig. 25. Decomposition of $\mathrm{H}_{2} \mathrm{O}_{2}$ at $35^{\circ} \mathrm{C}$ over $0.5 \% \quad \mathrm{Ni} / \mathrm{RSS} \quad(\mathrm{B}),(0.5 \% \mathrm{Ni}-$ $0.5 \% \mathrm{Cu}) / \mathrm{RSS}$ and $(0.5 \% \mathrm{Ni}-0.5 \% \mathrm{Co}) / \mathrm{RSS}$ nano catalysts.

Egypt. J. Chem. 57, No.3 (2014) 


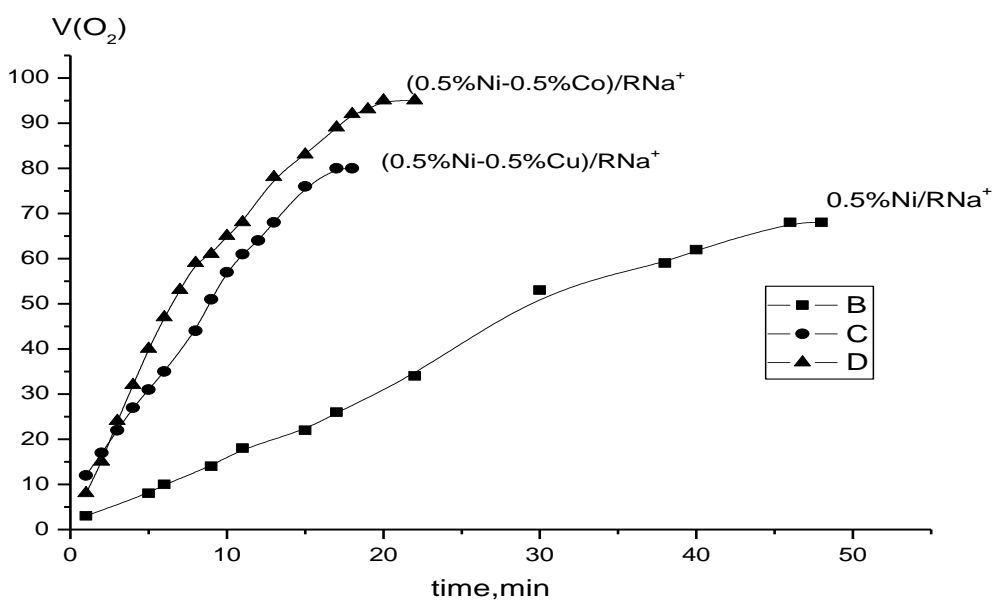

Fig. 26. Decomposition of $\mathrm{H}_{2} \mathrm{O}_{2}$ at $35^{\circ} \mathrm{C}$ over $0.5 \% \mathrm{Ni} / \mathrm{RNa}^{+}(\mathrm{B}),(0.5 \% \mathrm{Ni}-0.5 \% \mathrm{Cu}) /$ $\mathrm{RNa}^{+}$and $(0.5 \% \mathrm{Ni}-0.5 \% \mathrm{Co}) / \mathrm{RNa}^{+}$nano catalysts.

The reaction could be performed using different transition nano metals (bimetallic nanoparticles from $\mathrm{Ni}$ and $\mathrm{Cu}$ or $\mathrm{Co}$ supported on $\mathrm{RSS}$ or $\mathrm{RNa}^{+}$) to compare how will each catalyst works for the same reaction at $40^{\circ} \mathrm{C}$. A fair test must use the same amount of each catalyst $(0.1 \mathrm{~g}$ of monometallic nanoparticles or $0.2 \mathrm{~g}$ of supported bi-metallic nanoparticles, i.e., containing the same amount of nickel).

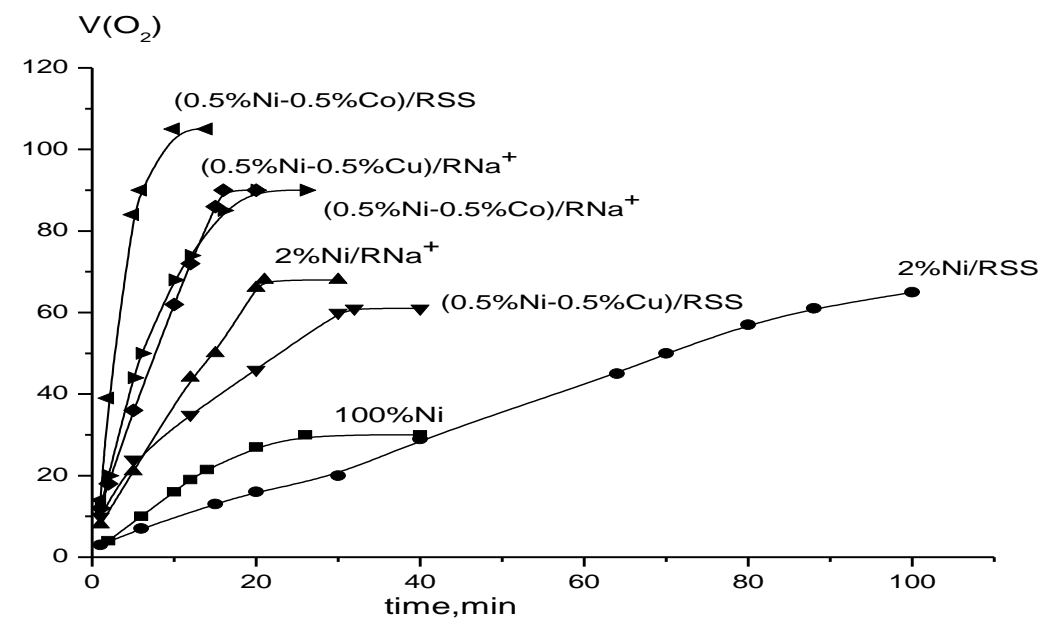

Fig. 27. Decomposition of $\mathrm{H}_{2} \mathrm{O}_{2}$ at $40^{\circ} \mathrm{C}$ over nano nickel and modified nickel with $\mathrm{Cu}$ or Co. 


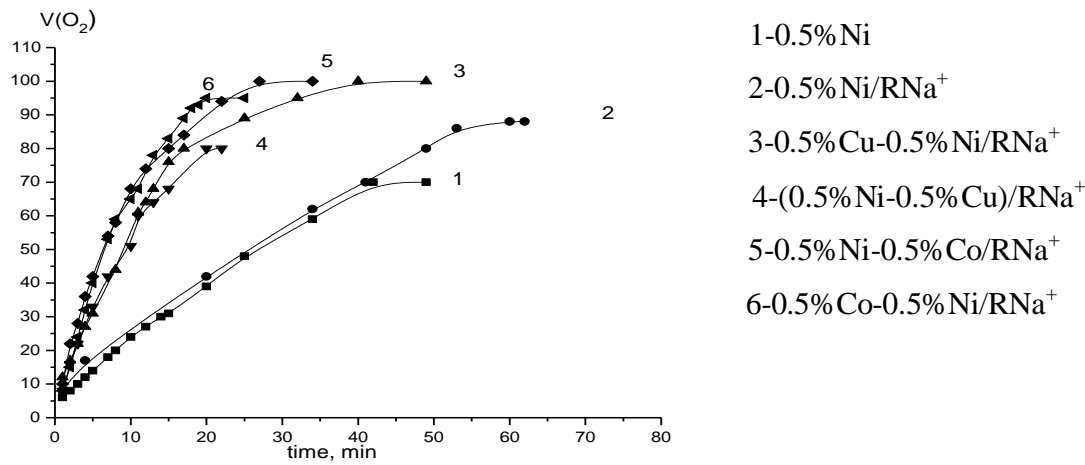

Fig. 28. Decomposition of $\mathrm{H}_{2} \mathrm{O}_{2}$ at $35^{\circ} \mathrm{C}$ over supported bi-metallic nanocatalysts prepared from their chlorides, $\left(\mathrm{M}_{1}-\mathrm{M}_{2} / \mathrm{RNa}^{+}\right)$.

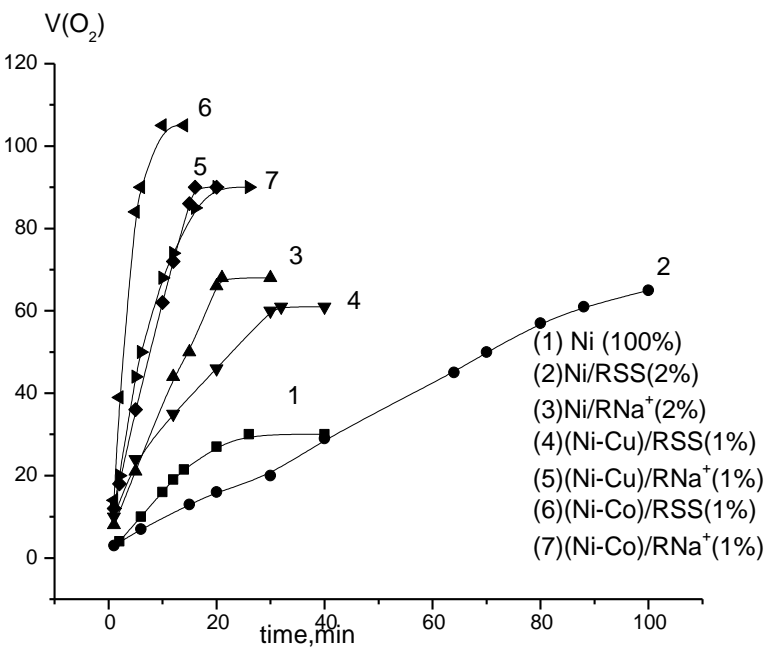

Fig. 29. Decomposition of $\mathrm{H}_{2} \mathrm{O}_{2}$ at $40^{\circ} \mathrm{C}$ over supported bi-metallic nanocatalysts prepared from their chlorides, $\left(0.5 \% \mathrm{M}_{1}-0.5 \% \mathrm{M}_{2} / \mathrm{RNa}^{+}\right.$or RSS).

Prepared samples of nano metals supported and unsupported catalysts reduce the activation energy and increase the rate of reaction although they do not change the final proportion of reactants and products.

The plots derived from Arrhenius equation is presented, and from plotting $\ln \mathrm{K}$ vs. 1/T, we can calculate (Ea) for first order decomposition reaction of hydrogen peroxide.

Egypt. J. Chem. 57, No.3 (2014) 

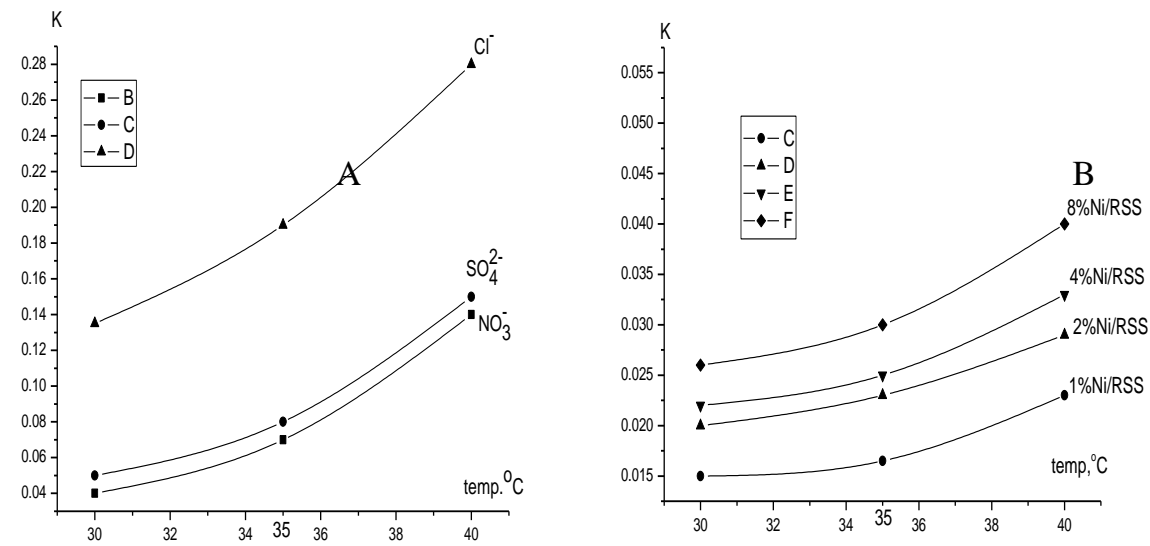

Fig. 30. A- Dependence of $\mathrm{K}$ vs.temp.for Ni NPs catalysts prepared from different precursors, from $\mathrm{Ni}\left(\mathrm{NO}_{3}\right)_{2}$, from $\mathrm{NiSO}_{4}$ and from $\mathrm{NiCl}_{2}$. B- Dependence of K vs.temp.for supported Ni NPs on RSS catalysts prepared from its chloride with different loads from $1 \%$ to $8.0 \%$ wt.in the hydrogen peroxide decomposition at different temperatures $\left(30^{\circ} \mathrm{C}, 35^{\circ} \mathrm{C}\right.$ and $\left.40^{\circ} \mathrm{C}\right)$.
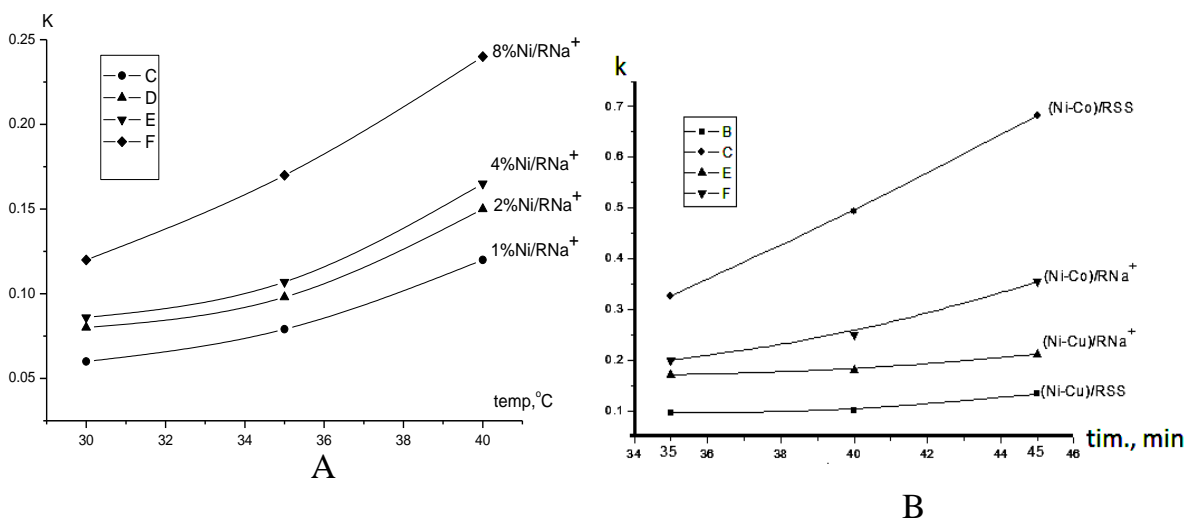

Fig. 31. A- Dependence of $K$ vs.temp.for supported $\mathrm{Ni}$ NPs on $\mathrm{RNa}^{+}$catalysts prepared from its chloride with different loads from $1 \%$ to $8.0 \%$ wt.in the hydrogen peroxide decomposition at different temperatures $\left(30^{\circ} \mathrm{C}, 35^{\circ} \mathrm{C}\right.$ and $40^{\circ} \mathrm{C}$ ). B- dependence of $\mathrm{K}$ vs.temp. ${ }^{\circ} \mathrm{C}$ for supporting material of immobilized Ni-based bimetallic nanocatalysts on RSS or $\mathrm{RNa}^{+}$catalysts and the metals prepared from their chlorides with constant load in the hydrogen peroxide decomposition at different temperatures $\left(35^{\circ} \mathrm{C}, 40^{\circ} \mathrm{C}\right.$ and $45^{\circ} \mathrm{C}$ ). 
TABLE 1. Rate constants $k$ and activation energy $\triangle \mathrm{Ea}$ for Ni nanocatalysts prepared from different precursors .

\begin{tabular}{|c|c|c|c|c|c|}
\hline \multirow{2}{*}{ Precursor } & \multirow[b]{2}{*}{ Catalysts } & \multicolumn{3}{|c|}{ Rate $\left(\min ^{-1}\right)$} & \multirow{2}{*}{$\begin{array}{c}\text { Activation } \\
\text { Energy } \\
\left(\text { k.Cal.mol }{ }^{-1}\right)\end{array}$} \\
\hline & & $\begin{array}{c}30^{\circ} \mathrm{C} \\
k \times 10^{-3}\end{array}$ & $\begin{array}{c}35^{\circ} \mathrm{C} \\
k \times 10^{-3}\end{array}$ & $\begin{array}{c}40^{\circ} \mathrm{C} \\
k \times 10^{-3}\end{array}$ & \\
\hline Nickel nitrate & $\mathrm{Ni}$ & 40 & 70 & 140 & 15.0 \\
\hline Nickel sulphate & $\mathrm{Ni}$ & 50 & 80 & 150 & 13.6 \\
\hline Nickel chloride & $\mathrm{Ni}$ & 135 & 190 & 280 & 13.4 \\
\hline
\end{tabular}

a has the highest rate constants $\mathrm{k}$ i.e., hydrogen peroxide decomposes faster than on $\mathrm{Ni}$ nanocatalysts prepared from nitrate and sulphate precursors. The observed increase in the activity of $\mathrm{Ni}$ nanocatalysts prepared from chloride precursor may be related to the presence of smaller particle size of nanocatalysts than that prepared from nitrate or sulphate precursors according the results obtained from TEM.

TABLE 2. Rate constants $k$ and activation energy $\Delta$ Ea for supported material of immobilized Ni-based monometallic nanocatalysts on RSS,prepared from its chloride with different loads.

\begin{tabular}{|c|c|c|c|c|c|}
\hline \multirow[b]{2}{*}{ Wt.\% Ni } & \multirow[b]{2}{*}{ Catalysts } & \multicolumn{3}{|c|}{ Rate $\left(\mathrm{min}^{-1}\right)$} & \multirow[b]{2}{*}{$\begin{array}{l}\text { Activation Energy } \\
\left(\text { K.Cal.mol }^{-1}\right)\end{array}$} \\
\hline & & $\begin{array}{c}30^{\circ} \mathrm{C} \\
\mathrm{k} \times 10^{-3}\end{array}$ & $\begin{array}{c}35^{\circ} \mathrm{C} \\
\mathrm{k} \times 10^{-3}\end{array}$ & $\begin{array}{c}40^{\circ} \mathrm{C} \\
k \times x_{3} 10^{-}\end{array}$ & \\
\hline $1 \%$ & $\mathrm{Ni} / \mathrm{RSS}$ & 15 & 16.5 & 23 & 8 \\
\hline $2 \%$ & $\mathrm{Ni} / \mathrm{RSS}$ & 20 & 23 & 29 & 6.7 \\
\hline $4 \%$ & $\mathrm{Ni} / \mathrm{RSS}$ & 22 & 25 & 33 & 7.4 \\
\hline $8 \%$ & $\mathrm{Ni} / \mathrm{RSS}$ & 26 & 30 & 40 & 7.3 \\
\hline
\end{tabular}

From Table 2, we can observe that increasing the loading of Ni/RSS from $1 \mathrm{wt} \%$ to $8 \mathrm{wt} \%$, increases the catalytic activity due to the increase of the number of active sites of the Ni NPs with good dispersion of these nano particles on the inert support.

TABLE 3. Rate constants $k$ and activation energy $\triangle E$ a for supported material of immobilized Ni-based monometallic nanocatalysts on $\mathrm{RNa}^{+}$,prepared from its chloride with different loads.

\begin{tabular}{|c|c|c|c|c|c|}
\hline \multirow[b]{2}{*}{ Wt.\% Ni } & \multirow[b]{2}{*}{ catalysts } & \multicolumn{3}{|c|}{ Rate $\left(\min ^{-1}\right)$} & \multirow[b]{2}{*}{$\begin{array}{l}\text { Activation Energy } \\
\quad\left(\mathbf{k . C a l} \mathrm{mol}^{-1}\right)\end{array}$} \\
\hline & & $\begin{array}{c}30^{\circ} \mathrm{C} \\
k \times 10^{-3}\end{array}$ & $\begin{array}{c}35^{\circ} \mathrm{C} \\
k \times 10^{-3}\end{array}$ & $\begin{array}{c}40^{\circ} \mathrm{C} \\
k x_{3} 10^{-}\end{array}$ & \\
\hline $1 \%$ & $\mathrm{Ni} / \mathrm{RNa}^{+}$ & 60 & 79 & 120 & 12.3 \\
\hline $2 \%$ & $\mathrm{Ni} / \mathrm{RNa}^{+}$ & 80 & 98 & 150 & 11.3 \\
\hline $4 \%$ & $\mathrm{Ni} / \mathrm{RNa}^{+}$ & 86 & 107 & 165 & 11.8 \\
\hline $8 \%$ & $\mathrm{Ni} / \mathrm{RNa}^{+}$ & 120 & 170 & 240 & 12.4 \\
\hline
\end{tabular}

Egypt. J. Chem. 57, No.3 (2014) 
From Table 3, we can observe that increasing the loading of $\mathrm{Ni} / \mathrm{RNa}^{+}$from $1 \mathrm{wt} \%$ to $8 \mathrm{wt} \%$, the catalytic activity increases due to the increases of the active sites of the Ni NPs with available dispersion of these nano particles on the inert material, and theses loading are small and suitable for dispersion on the surface of the inert material. Also, agglomeration not occurs as showed before in XRD analysis.

The activity of $\mathrm{Ni} /$ resin $(8 \%)$ was higher than the activity of unsupported nickel by three nano nickel, leads us to believe that all nickel act as active center for this reaction, the increase of nickel loading from $0.5 \%$ to $8 \%$ will increase the dispersion of nickel and hence all Ni can be susceptible to the reactant and the neighboring nanosized nickel particles can influence each other which is expressed by the existence of strain among them and it is seemed to be as the catalytic activity is proportional to the nano-nickel from its chloride and $8 \mathrm{wt}$ $\% \mathrm{Ni} /$ resin; the catalytic activity and durability are still being very high.

We can summarize the data as follows:

1-The constancy of energy of activation indicates the presence of the same active sites in all catalysts under investigation.

2- The increase of the Ni-content in catalysts accompanied by increase in the rate of reaction.

It is obvious, that this reaction is strongly affected by catalysts, such as transition nano metals ( $\mathrm{Ni}, \mathrm{Co}$ and $\mathrm{Cu}$ ), their loading on different inert materials such as silica (from rice straw RSS) and cation exchange resin $\mathrm{RNa}^{+}$. The hydrogen peroxide reacts rapidly. This effect is readily seen by the evolved oxygen. From the inspection of Table 4, it can be seen that, the activation energies for the decomposition of hydrogen peroxide over $\mathrm{Ni}-\mathrm{Cu} / \mathrm{RSS}$ and over $\mathrm{Ni}-\mathrm{Cu} / \mathrm{RNa}^{+}$are nearly the same between 5 and $6.5 \mathrm{k} \cdot \mathrm{cal} \cdot \mathrm{mol}^{-1}$. Also, for Ni$\mathrm{Co} / \mathrm{RSS}$ and $\mathrm{Ni}-\mathrm{Co} / \mathrm{RNa}^{+}$are nearly the same between 13 and $14.4 \mathrm{k} . \mathrm{cal}^{-\mathrm{mol}^{-1}}$. This means that, the access the same energy of activation means the existence of the same active sites, and the access of different energy of activation means different active sites.

TABLE 4. Rate constants $k$ and activation energy $\triangle E$ a for supporting material of immobilized Ni-based bimetallic Nanocatalysts on RSS or $\mathrm{RNa}^{+}$, which prepared from their chloride.

\begin{tabular}{|c|c|c|c|c|}
\hline \multirow[b]{2}{*}{ Catalysts } & \multicolumn{3}{|c|}{ Rate $\left(\mathrm{min}^{-1}\right)$} & \multirow{2}{*}{$\begin{array}{l}\text { Activation Energy } \\
\quad\left(\text { k.Cal.mol }{ }^{-1}\right)\end{array}$} \\
\hline & $\begin{array}{c}35^{\circ} \mathrm{C} \\
k \times 10^{-3}\end{array}$ & $\begin{array}{c}40^{\circ} \mathrm{C} \\
k \times 10^{-3}\end{array}$ & $\begin{array}{c}45^{\circ} \mathrm{C} \\
k \times 10^{-3}\end{array}$ & \\
\hline$(0.5 \% \mathrm{Ni}-0.5 \% \mathrm{Cu}) / \mathrm{RSS}$ & 96 & 100 & 134 & 6.6 \\
\hline$(0.5 \% \mathrm{Ni}-0.5 \% \mathrm{Co}) / \mathrm{RSS}$ & 327 & 490 & 683 & 14.4 \\
\hline$(0.5 \% \mathrm{Ni}-0.5 \% \mathrm{Cu}) / \mathrm{RNa}^{+}$ & 170 & 180 & 212 & 5.1 \\
\hline$(0.5 \% \mathrm{Ni}-0.5 \% \mathrm{Co}) / \mathrm{RNa}^{+}$ & 200 & 250 & 345 & 13 \\
\hline
\end{tabular}




\section{Conclusions}

The present work deals mainly with supported and unsupported nickel catalyst in the decomposition of hydrogen peroxide reaction. The nickel was obtained from different precursors (chloride, nitrate or sulphate).

The supports were silica and cation exchange resin. Silica was prepared from rice straw by treatment with nitric acid followed by sodium hydroxide, precipitated with nitric and calcined at $600^{\circ} \mathrm{C}$. The amounts of nickel on the supported ranged from $0.5 \mathrm{wt} . \%$ up to $8.0 \mathrm{wt} . \% \mathrm{Ni}$ on silica or resin.

Other catalysts were prepared containing $\mathrm{Cu}$ - $\mathrm{Co}$ - separately on supports or in combinations $\mathrm{Ni}-\mathrm{Cu}$, Ni-Co also loaded on the same supports.

The preparation of the nanocatalysts were prepared using hydrazine hydrate as reducing agent i.e., hydrogen donor.

The analysis by XRD showed that metallic nickel was obtained by reduction. The reduced metal was in nano-size as showed by TEM. Nanonickel prepared from chloride exhibited the smallest particle size and showed the highest catalytic activity. The combination of $\mathrm{Ni}$ with $\mathrm{Cu}$ - or $\mathrm{Co}$ - increased the catalytic activity of nickel catalyst.

The constancy of the energy of activation confirms the presence of the same active sites. The increase of the activities points to the increase of the number of the active sites.

\section{References}

1. Hamer, D.W. and Biggers, J.V., Thicks Film Hybrid Micro-circuit Technology, Wiley- Interscience, New York (1972).

2. Haque, K.M. A., Hussain, M. S. and Alam, S. S., Effect of temperature on the synthesis of nano-nickel particles. National and Nanotechnology, 2(4), 104-108 (2012).

3. Goia, D.V., Burn, I. and Varga, G., Advanced Technologies of Particles synthesis for Electronics applications. ECCE-European Congress of Chemical Engineering, June 26-28, Nuremberg, Germany (2001).

4. Bonnemann, H. and Brijoux, W., In: Advanced Catalysis and Nanostructered Materials, Ed. W. R. Moser, Academic Press, San Diago, p165 (1996) .

5. Busser, G. W., Van Ommen, J. G. and Lercher, J. A., In: Advanced Catalysis and Nanostructered Materials, Ed. W. R. Moser, Academic Press, San Diago, p213(1996).

6. Hwang, J.H., Dravid, V.P., Teng, M.H., Host, J.J., Elliott, B.R., Johnso, D.L. and Mason, T.O., Magnetic properties of graphically encapsulated nickel nano crystals [J]. J. Mater Res, 12(4), 1076-1082 (1997).

Egypt. J. Chem. 57, No.3 (2014) 
7. Stopic, S., Llic, I. and Uskokovic, D.P., Preparation of nickel submicron powder by ultrasonic spray pyrolysis [J]. Int. J. Powder Metal, 32(1), 59-65(1996).

8. Xia, B., Lenggoro, I.W. and Okuyama, K., The role of ammonia and ammonium bicarbonate in the preparation of nickel particles from nickel chloride [J]. Mater Res. 15(10), 2157-2166(2000).

9. Ni, X.M., Su, X.B. and Yang, Z.P., The preparation of nickel nan rods in water-in-oil micro emulsion [J]. J. Crystal Growth, 252(4), 612-617 (2003).

10. Szu-Han Wu and Dong-Hwang, Synthesis and characterization of nickel nanoparticles by hydrazine reduction in ethylene glycol. Journal of Colloid and interface Sceience, 259, 282-286(2003).

11. Wang, W., Song, M., Zhang, Z.Y. and Richardson, M., Synthesis and characterization of high nickel-containing mesoporous silica via a modified direct synthesis method. Journal of Non-Crystalline Solids, 3522,180-2186(2006).

12. Selim, M.M., Abd El Masksod, I.H. and Saleh, T.S., The use of nano supported nickel catalyst in reduction of p-Nitrophenol using hydrazine hydraate as hydrogen donor. Egypt. J.Chem. 52(4), 491 (2009).

13. Bhanu, P.S. and Chauhan Hybrid, Nanomaterials: Synthesis, Characterization and Applications. Copyright, by John Wily \& Sons (2011).

14. Benjaram, M. Reddya , Gundapaneni M. Kumara, Ibram Ganesh, B. and Ataullah Khana, Vapour phase hydrogenation of cinnamaldehyde over silica supporte transition metal-based bimetallic catalysts. Journal of Molecular Catalysis A: Chemical, 247, 80-87 (2006).

15. Guangjun Cheng and Ting Guo, Surface segregation in $\mathrm{Ni} / \mathrm{Co}$ bimetallic nanoparticles produced in single-walled carbon nanotube synthesis. J. Phys. Chem. B 106, 5833-5839 (2002).

16. Bonet, F., Grugeon, S., Dupont, Herrera, Urbina, R., Guery, C. and Tarascon, J. M., Synthesis and characterization of bimetallic Ni-Cu particles. Journal of Solid State Chemistry, 172,111-115 (2003).

17. Choi, J.Y., Lee, Y.K., Yoon, S.M. and Lee, H.C., A chemical route to large-scale preparation of spherical and monodisperse Ni powders [J]. J. Am Ceram Soc. 88(11), 3020-3023 (2005).

18. Kim, K.M., Lee, J.H., Yoon, S.M. and Lee, H.C., Preparation of mono-disperse Ni powders via the reduction of hydrazine complexes: The effect of source materials and impurities [J]. J. Electroceram, 17, 339-343 (2006).

19. Hassan, S.A., Mekewi, M.A., Shebl, F.A. and Sadek, S.A., Effect of thermal treatment on various charateristics of undoped and $\mathrm{V}_{2} \mathrm{O}_{5}$-doped $\mathrm{Co}_{3} \mathrm{O}_{4} / \mathrm{TiO}_{2}$ catalysts. Journal of Materials Science, 26, 3712-3720(1991).

(Received $18 / 5 / 2014$ accepted 9/6/2014) 


\title{
الخصائص الفيزيائية للحفاز ذو الفلز الواحد و ذو الفزين للنيكل المتناهي الصغر على مواد حاملة مختلفة لفئة
}

\author{
سوزان فرغلى طنطاوى ، صلاح عبده حسن" ، شوقى حسن جبر ومحمد محمد

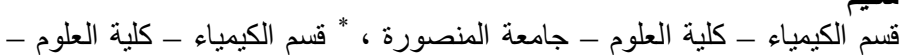 \\ جامعة عين شمس و ** المركز القومى للبحوث ــ القاهرة - مصرة.
}

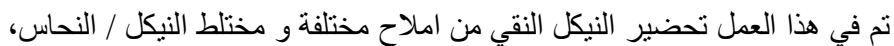

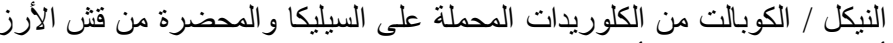

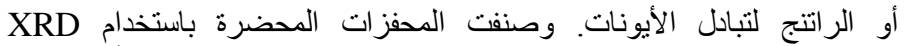
والتم اختبار النشاط الحفزى في تكسير

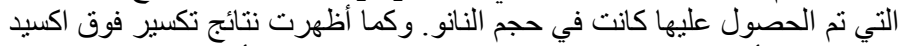
الهيدروجين أن حفاز نانو نيكل المحضر من الكلوريد كان أكثر نشاطا من التهات النيكل

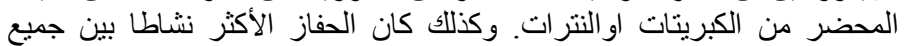

العينات المحضرة هو حفاز الكوبالت و النيكل على السيليكات. 